Özdemir, Y. ve Kıroğlu, K. (2018). Sınıf öğretmenlerinin içerik okuma ile ilgili görüşleri. Ana Dili Eğitimi Dergisi, 6(4), 924-944.

$\begin{gathered}\text { Ana Dili Eğitimi Dergisi } \\ \text { Journal of MotherTongueEducation } \\ \text { www.anadiliegitimi.com }\end{gathered}$
Gelis/Received: 27.05 .2018 Kabul/Accepted:27.07.2018

\title{
Sınıf Öğretmenlerinin İçerik Okuma ile İlgili Görüşleri*
}

\author{
Yusuf ÖZDEMIR ${ }^{* *}$ \\ Kasım KIROĞLU***
}

Öz

İlkokul üçüncü sınıftan dördüncü sınıfa geçen öğrencileri zorlu bir yıl beklemektedir. Artık alan derslerinde okuma yapmaları gerekecektir. Alan derslerinde ise ilk üç yılda fazla alışık olmadıkları farklı içeriklerde metinler kullanılmaktadır. Ilkokulun ilk yıllarında daha çok yazınsal metinler üzerinde çalışan, bilgilendirici metinleri çok az kullanan öğrencilerden, dördüncü sınıf itibari ile farklı alanlar ile ilgili metinleri okuyup bilgiye ulaşmaları istenmektedir. İçerik okuma, sosyal bilgiler, fen bilimleri, matematik gibi farklı disiplinlerdeki okuma faaliyetlerini içermektedir. Bir nevi bu derslerde verilen yeni içeriği kazanabilmek için gerekli olan okuma becerisi olarak tanımlanabilmektedir. "Her öğretmen bir okuma öğretmenidir." sözünden hareketle her ders bir anlamda okuma dersidir, denilebilir. Bunun için her derste öğrencilerin okuduğunu anlama becerisini geliştirmek için çalışmaların yapılması bir zorunluluk haline gelmektedir. Alan öğretmenlerinin daha çok öğrencilerin alan bilgisi üzerinde durmaları, kendilerini okuma öğretmeni olarak görmemeleri ve bu alanda eğitim de almamaları, sınıf öğretmenlerinin bu alanlarda yaptıkları okuma uygulamalarını daha önemli hale getirmektedir. Bu araştırmada sınıf öğretmenlerinin alan derslerinde okuma öğretimi ile ilgili neler yaptıklarının ortaya çıkarılması amaçlanmıştır. Araştırma 2015-2016 eğitim-öğretim yılında, Samsun ilinin Alaçam ilçesinde görev yapan ve amaçlı örnekleme yolu ile belirlenen 20 öğretmen ile gerçekleştirilmiştir. Araştırmada nitel araştırma yöntemlerinden görüşme yöntemi kullanılmıştır. Araştırmanın verileri araştırmacı tarafından ilgili alanyazın incelenerek oluşturulan yarı yapılandırılmış görüşme formu ile toplanmıştır. Nitel verilerin analizinde ise betimsel analiz yöntemi kullanılmıştır. Araştırmanın sonucunda sınıf öğretmenlerinin okuma ile ilgili ilkokuma yazma öğretimi dışında herhangi bir kurs almadıkları görülmüştür. Sınıf öğretmenlerinin içerik metinlerini okumadan önce soru sorma; okurken önemli yerleri belirtme ya da not aldırma; okuma bittikten sonra ise özetleme ya da test çözme gibi uygulamalar yaptıkları belirlenmiştir. Ilkokul dördüncü sınıflarda içerik okuma stratejilerinin nadiren kullanıldığı sonucuna ulaşılmıştır.

Anahtar Kelimeler:Içerik okuma, sınıf öğretmeni, anlama stratejileri

\section{Primary School Teachers' Opinions about the Content Area Reading}

\begin{abstract}
The forth grade primary school students will have a difficult year since they will need to read in different content areas. In the content areas, informative texts are used. Students who study on literary texts and use very little informative texts in the first three years of primary schoolare required to read texts related to different content areas in order to acquire knowledge starting from the fourth grade. The content area reading includes reading activities in different disciplines such as social sciences, science, mathematics. Content area reading can be defined as having reading comprehension skills which are essential to understand new content included in those disciplines. With reference to a common saying

\footnotetext{
*XV. Uluslararası Sınıf Öğretmenliği Eğitimi Sempozyumu'nda sözlü bildiri olarak sunulmuştur.

** Dr., Şehit Muhammet Ali Aksu ilkokulu, Samsun, yusuefozdemir@hotmail.com

****Doç. Dr., Ondokuz Mayıs Üniversitesi, Eğitim Fakültesi, Sınıf Eğitimi Bölümü, Samsun, november@omu.gov.tr
} 
which is "every teacher is a reading teacher", it can be said that each lesson is a reading lesson. For this reason, it is crucial to improve comprehension skills of each and every student. The fact that content area teachers mostly focus on students' knowledge of the area, do not perceive themselves as teachers of reading and do not receive education in this field makes the reading practices of primary school teachers more important. For this reason, in this research, it is aimed to reveal the practices that primary school teachers are carrying out to teach reading in their content area. The research was carried out with 20 teachers who worked in Alaçam province of Samsun and determined by purposive sampling in 2015-2016 academic year. Qualitative research method was used in the study. The data of the research was collected by the researchers through semi-structured interview form which was formed by reviewing the literature. During the analysis of qualitative data, descriptive analysis method was used. As a result of the research, it was determined that the class teachers did not take any courses related to reading apart from primary school reading-writing instruction. Additionally, it was found out that classroom teachers ask questions before reading; identify important points by underlining or make students take notes while reading; assess students through tests or summarization activities after reading in the content areas. As a result, it was figured out that content area reading strategies were rarely used.

Keywords: Content area reading, classroom teacher, comprehension strategies

\section{Giriş}

Bireyin hayatına yön veren önemli becerilerden biri okumadır. Bireyin akademik, sosyal, duygusal gelişimine yön veren bu beceriyi geliştirme çalışmaları her zaman ilgi çekici olmuştur. Okul öncesinde sesleri sezdirme ile başlayan okuma çalışmaları ilkokulda seslerin öğretimi ile devam eder. ilkkokulun ilk yıllarında okuma becerisini kazanan öğrencilerden artık öğrenmek için okuması beklenmektedir.

“Öğrenmek için okuma” okuma becerisinin öğretilmesindeki asıl amaçlarından birisidir (Coşkun, 2002; Güneş, 2012). Okuma bilgiye ulaşmanın kolaylaştığı günümüzde bireyin bağımsız olarak öğrenebilmesinin yolunu açmaktadır. Ancak bilgiye ulaşabilmek okuma becerisini kazanmanın yanı sıra bu becerinin bilgi edinebilmek için kullanılabilmesini gerektirmektedir. Son yıllarda yapılan çalışmalara bakıldığında öğrencilerin okuduğunu anlamada problemler yaşadığı ortaya konmaktadır (Sidekli, 2005; Tayşi, 2007; Yıldııı, Yıldız, Ateş ve Rasinski, 2010; Dymock ve Nicholson, 2010). Bu durum metinlerdeki bilgiye ulaşabilmenin önündeki önemli engellerden biridir.

Bilgi elde etmek için okumak, akademik başarının önemli belirleyicilerinden biridir. Öğrenciler okulda birçok içerikle karşı karşıya kalmaktadırlar. Bu içeriklerin büyük bir kısmında öğrencilere bilgiler bilgilendirici metinlerle sunulmaktadır. Her ne kadar metinler bilginin tek kaynağı olarak önerilmeseler de hala metinler bilginin yapılandırılması, deneyimlerin paylaşılması, yeni bakış açılarının ortaya atılması için önemli araçlardır (Vacca ve Vacca, 2005). Öğrenci sosyal bilgiler dersinde Kurtuluş Savaşı ile ilgili bir metin okuduktan sonra fen bilimleri dersinde canlıların özellikleri ile bir metinle karşı karşıya gelebilir. Ardından matematik dersinde çözmesi gereken bir problemi okuması gerekir. Bu derslerin her birinde okuma becerisini kullanarak bilgiye ulaşabilmelidir. Özellikle sosyal bilgiler gibi yazılı kaynakların çok fazla kullanıldığı alanlarda bu durum daha belirgin olarak gözlenebilmektedir. Sınıf öğretmenleri ile yapılan bir çalışmaya göre sınıf öğretmenleri sosyal bilgiler 


\section{Sınıf Öğretmenlerinin İçerik Okuma ile ilgili Görüşleri}

dersinde öğrencilerin dil becerilerinin çok önemli bir yere sahip olduğunu belirtmişlerdir. Öğrenciler derste metinleri okurlar, daha sonra bu metinlerle ilgili sorular cevaplanır sonrasında ise metnin özeti yazılır (Karadağ ve Çengelci, 2011). Bu uygulamalara diğer derslerde de rastlanmaktadır.

Metinlerin okunması, bu metinlerle ilgili sorular sorulması veya var olan soruların cevaplanması metni anlamaya yönelik yapılan uygulamalardır. Ancak bu uygulamalar öğrencileri hem pasif durumda tutarken hem de onların metinle ilgili bakış açısı oluşturmalarını engellemektedir (Vacca ve Vacca, 2005). Bir metni anlamak okuyucunun ön bilgileri, ilgileri, amacl; metnin dili ve kavramsal zorluğu; yazarın metni oluşturma biçimi ile yakından ilgilidir (Vacca ve Vacca, 2005). Birden fazla değişkene bağlı olan anlam kurma sürecinde bireyin mutlaka bilinçli etkinliklerle anlamı yapılandırması gerekmektedir. Anlam kurma, kod çözme becerisinden çok daha ileride ve ömür boyu geliştirilmesi gereken bir beceridir. Anlama için sorgulama, analiz etme ve değerlendirme gibi üst düzey beceriler üzerinde durulmalıdır (Taş ve Kıroğlu, 2018). Bu nedenle okuma becerisini geliştirmeye yönelik etkinliklere her kademede yer verilmelidir.

Illkokul dördüncü sınıftan itibaren öğrencilerin karşılaştıkları önemli sorunlardan biri farklı alanlardaki metinleri anlamada zorluk yaşamalarıdır. Bu alanlarda daha çok bilgilendirici metinler yer almakta ve bu metinleri anlamada öğrenciler zorlanmaktadır (Tayşi, 2007; Yıldıım, Yıldız, Ateş ve Rasinski, 2010). Bu zorluğa motivasyonel, bilişsel, durumsal faktörler neden olabilir. Öncelikle öğrenciler bu metinlerle çok sık karşı karşıya gelmemektedirler. Bu durum metinlerle karşı karşıya gelindiğinde öğrencilerin motivasyonunu olumsuz etkileyebilir. Çünkü bu metinler bilgi yüklü ve bilinmeyen kavramların yer aldığı metinlerdir. Bilişsel açıdan bakıldığında metinlerdeki bilgilerin seçimi, organize edilmesi ve bütünleştirilmesi gibi süreçler metinden anlam oluşturmak için önemlidir. Öğrencinin öncelikle dikkatini metne vererek amacına uygun bilgileri seçebilmesi gerekir. Seçilen bilgiler birbiri ile uyumlu bir şekilde organize edilmelidir. Son olarak bu bilgiler var olan bilgilerle bütünleştirilmelidir (Armbruster, Anderson ve Meyer, 1990). Bilgilendirici metinlere has bahsedilen zorlukların aşılması bu metinlerin üzerinde bilinçli etkinliklerin yapılmasına bağlıdır. Alan dersleri bu konuda öğrencilere temel bir uygulama alanı sunmakta ve bu eksikliğin giderilmesi için uygun bir ortam hazırlamaktadır. Bu zorluğu gidermek için bu alanların her birine ait metinlerin okunmasına yönelik yapılan uygulamalara alan yazında "içerik okuma" olarak yer verilmektedir (McKenna ve Robinson, 1990).

İçerik, belli bilgi kategorilerinden (disiplinlerden) oluşmaktadır (Demirel, 2012). Farklı disiplinlere ait bilgiler bir içerik dâhilinde okuyucuya sunulur. İçerik okuma, verilen bu içeriklerdeki bilgiyi elde edebilmek için okuma becerisini kullanabilme yeteneği olarak tanımlanabilmektedir (McKenna ve Robinson, 1990). İçerik okuma öğretimi, öğrencilerin sosyal bilgiler, fen bilimleri, edebiyat, matematik gibi alanlardaki metinleri anlamalarında yardımcı olmak için tasarlanır (Grierson 
ve Daniel, 1995: 4). Her akademik disiplinin kendine özgü okuma özellikleri bulunmaktadır. Çünkü metin tipi, sözlük, metin yapısı, amaç, hedef kitlesi disiplinler arasında farklılık göstermektedir. Bir sosyal bilgiler kitabı bir matematik kitabından; ders kitapları da gazete makalelerinden, internete dayalı hiper metinlere kadar birçok metin tipinden farklılaşmaktadır (Heller ve Greenleaf, 2007). İ̧̧erik okuma bu noktada üç bilişsel bileşeni ortaya koymaktadır: Genel okuryazarlık becerileri, içeriğe özel okuryazarlık becerileri, içeriğe özgü ön bilgiler (Grierson ve Daniel, 1995).

Genel okuryazarlık becerileri içinde okuma becerisinin etkinliğini ses farkındalığı, ses öğretimi, akıcılık, kelime bilgisi ve anlama boyutlarındaki gelişme belirlemektedir (NRP, 2000). Özellikle okuma öncesi, esnasında ve sonrasında kullanılan anlama stratejilerinin okuduğunu anlamada etkili olduğu ortaya konmaktadır (Heller ve Greenleaf, 2007). Bu boyutlardaki gelişmenin yanı sıra herhangi bir alana özgü okuma becerilerinin gelişmesi de içerik okuma için oldukça önemlidir. Örneğin, fen bilimlerinde öğrenciler belirli bilimsel gerçekleri, yasaları ve ilkeleri öğrenmek için okuyabilirler. Ancak fen bilgisi ile ilgili bir metinde her okunan, gerçek ya da mutlak olarak ele alınmamalıdır. Bu nedenle öğrenciler, gerçekler ve teoriler arasındaki farkların neler olduğunu belirlemeyi ve anlamayı öğrenmeye ihtiyaç duyarlar (Hall, 2005). İçerik okumada bilgiye ulaşmayı sağlayan bir sonraki unsur o içeriye özgü ön bilgilerdir. Ön bilgiler okuduğunu anlamanın önemli belirleyicilerinden biridir. iç̧erik alanlarında farklı kavramlara çokça yer verildiği için öğrencilerin bu kavramlara ilişkin ön bilgileri oldukça önemlidir. Bu nedenle içerik alanı okuma uygulamaları içerikle ilgili ön bilgilere önem vermektedir. Örnek olarak aşağıdaki paragrafı (Bilim Çocuk Dergisi, 2014-194) inceleyebiliriz.

Bazı hayvanların yollarını ses dalgalarının yansımasından yararlanarak bulduğunu biliyor musunuz? Yunuslar, balinalar, yarasalar gibi. Yarasalar karanlıkta yollarını bulmak ve avlarını yakalamak için ses dalgalarından yararlanır. Bu hayvanlar insanların duyamayacağı kadar yüksek titreşimli yani çok tiz sesler çıkarır. Bu sesler nesnelerden yansıyarak geri döner. Yarasalar yansıyan sesler sayesinde önlerindeki nesnelerin konumlarını, şekillerini ve büyüklüklerini algılar.

Ses dalgaları, tiz sesler, titreşim, yansıma gibi kelimeler bu paragrafın anlaşılması için önemli olan fen bilimleri ile ilgili kavramlardır. Öğrencilerin okuma öncesi ön bilgilerini geliştirecek çalışmalar içerik okumanın önemli bir işlevi olarak görülmektedir.

İçerik okuma ile ilgili karşımıza çıkan sorunlardan biri bu metinleri anlamaya yönelik uygulamaların kim tarafından yapılacağı sorunudur. Öğrenciler alan dersleri ile tanışmaya dördüncü sınıfta başlamalarına rağmen alan dersleri ile yoğun bir şekilde ortaokul ve lisede karşı karşıya gelmektedirler. Bu nedenle içerik okuma çalışmaları genel olarak ortaokullarla eşleştirilmektedir. Bunun yanında okuma öğretimi de genellikle ilkokulla eşleştirilir. İçerik okumanın "Her öğretmen okuma öğretmenidir." sloganı bütün öğretmenleri okuma öğretiminden sorumlu tutsa da ortaokul ve lise öğretmenleri kendilerini derslerinin öğretmeni kabul ederler ve bunun sorumluluğunu 


\section{Sınıf Öğretmenlerinin İçerik Okuma ile İlgili Görüşleri}

ilkokullarda görürler (Manzo, Manzo ve Estes, 2001; Vacca ve Vacca, 2005). Ortaokul ve lise öğretmenleri okumanın rolünü oldukça önemseseler de bunu kendilerinin görevi olarak görmezler (Ness, 2006). Bu kadar önemli bir rolü kendi sorumluluk alanlarında görmemelerinin bazı haklı nedenleri bulunmaktadır. Öncelikle okuma öğretimi öğretmenlerin aldıkları eğitimin bir parçası olmayabilir (Park ve Osborne, 2006: 2). Bu da yapılacak uygulamaların yararları ve uygulanması ile ilgili bilgi eksikliğine neden olabilir. Öğretmenlerin yetiştirmesi gereken bir programları vardır ve bu programların dışında yapılacak uygulamaların programı yetiştirememelerine neden olacağını düşünebilirler.

Günümüzde yapılan çalışmalara bakıldığında öğrencilere anlamaya yönelik stratejilerin öğretiminin yanında fen bilimleri, sosyal bilimler veya matematik alanları ile birlikte okuryazarlık becerilerinin öğretiminin yapıldığı bütünleştirilmiş programlarla da karşılaşılmaktadır (Williams, Stafford, Lauer, Hall ve Pollini, 2009; Cervetti, Barber, Dorph, Pearson ve Goldschmidt, 2012). Bu uygulamaların etkili sonuçlar verdiği araştırma sonuçlarında ortaya konmuştur. Bireyin temel becerileri olarak dört dil becerisini ele aldığımızda bu becerilerden bağımsız olarak diğer becerilerin geliştirilmesinin zor olacağı ortadadır. Bu nedenle farklı alanlarda yapılan dil becerileri ile ilgili uygulamaların neler olduğunun ve bunların nasıl uygulandığının ortaya konması oldukça önemlidir.

Okuma öğretiminin hayat boyu devam eden bir süreç olması, içerik ile okuma arasındaki ilişkinin erkenden kurulmasını ve çalışmaların erken yaşlardan itibaren okul hayatı boyunca programlı bir şekilde yapılmasını gerektirmektedir. Bu sürecin temeli ilkokuldur ve ilkokul sürecince yapılan uygulamaların neler olduğu hakkında bir merak oluşmaktadır (Grierson ve Daniel, 1995: 5). Bu nedenle çalışmada, ilkokul dördüncü sınıf öğretmenlerinin alan derslerinde okuma becerisine yönelik etkinlikleri nasıl yönlendirdiklerinin ortaya konulması amaçlanmıştır. Araştırmanın amacı doğrultusunda araştırmada şu problemler ele alınmıştır:

1- Sınıf öğretmenlerinin içerik okuma ile ilgili aldıkları eğitim nedir?

2- Sınıf öğretmenleri alanı derslerinde ders kitabındaki metinleri hangi sıklıkta ve nasıl kullanmaktadır?

3- Sınıf öğretmenleri metni okutmadan önce ne yapmaktadırlar? Metinde anlamı bilinmeyen kelimeler ile ilgili çalışmalar nasıl yapılmaktadır?

4- Sınıf öğretmenleri metindeki önemli fikirleri nasıl ortaya çıkarmaktadır?

5- Sınıf öğretmenleri metni öğrencilere nasıl okutmaktadır ve metin okunurken öğretmenin rolü nedir?

6- Sınıf Öğretmeni okumayı bitirdikten sonra neler yapmaktadır? 
7-Öğrencilerin içerik okuma sırasında karşılaştıkları sorunlar nelerdir? Sınıf öğretmenlerin karşılaşılan bu sorunlara yönelik çözümleri nelerdir?

\section{Yöntem}

\section{Araştırmanın Modeli}

$\mathrm{Bu}$ araştırmada nitel araştırma yöntemlerinden durum çalışması kullanılmıştır. Durum çalışmasında, sınırları belirlenmiş bir araştırma konusunun gerçek ortamında ayrıntılı bir şekilde betimlenmesi ve incelenmesi amaçlanır (Leymun, Odabaşı ve Yurdakul, 2017). Araştırmada veri toplama yöntemi olarak yarı yapılandırılmış görüşme yöntemi kullanılmıştır. Yarı yapılandırılmış görüşme yönteminde araştırmacı önceden sormayı planladığı soruları hazırlar. Araştırmacı görüşme esnasında yan ve alt sorularla görüşmenin akışını değiştirebilir (Patton, 2014: 343). Bu durum görüşmeciye hem belli bir standart hem de esneklik tanır (Türnüklü, 2000). Ayrıca görüşmecinin sınırlı olan zamanını en verimli şekilde kullanmasını sağlar (Patton, 2014: 343). Görüşme yöntemi; esnek olma, bireylerden bire bir doğru bilgi etme, derinlemesine bilgiye ulaşma gibi güçlü yönlere sahiptir (Yıldırım ve Şimşek, 2013).

\section{Araştırma grubu}

Araştırmanın grubunu 2015-2016 öğretim yılında Samsun ilinin Alaçam ilçesinde görev yapan 20 dördüncü sınıf öğretmeni oluşturmaktadır. Araştırma grubu amaçlı örnekleme yöntemlerinden maksimum örnekleme yöntemi ile belirlenmiştir. Maksimum örnekleme yönteminde örneklem, problem ile ilgili kendi içinde benzeşik farklı durumlardan oluşturulmaktadır (Büyüköztürk, Çakmak, Akgün, Karadeniz ve Demirel, 2010).

Tablo 1.Araştırma grubunu oluşturan sınıf öğretmenlerinin özellikleri

\begin{tabular}{|c|c|c|c|c|c|c|c|c|c|}
\hline Katılımcı & Kod & Kıdem & Mezuniyet & Okul Türü & Katılımcı & Kod & Kıdem & Mezuniyet & Okul Türü \\
\hline $1 \mathrm{E}$ & Ö1 & 14 & Eğt. Fak. & Taşımalı io & $11 \mathrm{~K}$ & Ö11 & 26 & Eğt. Fak. & Merkez io \\
\hline $2 \mathrm{~K}$ & Ö2 & 14 & Eğt. Fak. & Taşımalı io & $12 \mathrm{~K}$ & Ö12 & 14 & Eğt. Fak. & Merkez io \\
\hline $3 \mathrm{~K}$ & Ö3 & 13 & Eğt. Fak. & Taşımalı io & $13 \mathrm{~K}$ & Ö13 & 28 & Eğt. Fak. & Merkez io \\
\hline $4 \mathrm{E}$ & Ö4 & 27 & Eğt. Fak. & Merkez io & $14 \mathrm{E}$ & Ö14 & 36 & Eğt. Ens. & Merkez io \\
\hline $5 K$ & Ö5 & 24 & Eğt. Fak. & Merkez io & $15 \mathrm{E}$ & Ö15 & 26 & Eğt. Fak. & Merkez io \\
\hline $6 \mathrm{E}$ & Ö6 & 21 & Eğt. Fak. & Merkez io & $16 \mathrm{E}$ & Ö16 & 11 & Eğt. Fak. & Merkez io \\
\hline $7 \mathrm{E}$ & Ö7 & 9 & Eğt. Fak. & Merkez io & $17 \mathrm{E}$ & Ö17 & 6 & Eğt. Fak. & Taşımalı io \\
\hline $8 \mathrm{~K}$ & Ö8 & 15 & Eğt. Fak. & Taşımalı io & $18 \mathrm{~K}$ & Ö18 & 9 & Eğt. Fak. & Taşımalı ìo \\
\hline $9 \mathrm{E}$ & Ö9 & 37 & Eğt. Ens. & Taşımalı io & $19 \mathrm{~K}$ & Ö19 & 10 & Eğt. Fak. & Taşımalı ío \\
\hline $10 \mathrm{E}$ & Ö10 & 10 & Eğt. Fak. & Taşımalı io & $20 \mathrm{E}$ & Ö20 & 8 & Eğt. Fak. & Taşımalı ìo \\
\hline
\end{tabular}

kıdemleri 6 yıl ile 37 yıl arasında değişiklik göstermektedir. İki sınıf öğretmeni Eğitim Enstitüsü 


\section{Sınıf Öğretmenlerinin İçerik Okuma ile ilgili Görüşleri}

mezunu iken 18 sınıf öğretmeni Eğitim Fakültesi mezunudur. Öğretmenlerden 10 tanesi merkez ilkokullarda çalışırken 10 tanesi taşımalı ilkokullarda çalışmaktadır.

\section{Veri Toplama Araçları}

Araştırmada veri toplamak için yarı yapılandırılmış görüşme formu hazırlanmıştır. Görüşme formu hazırlanırken alan yazın incelenmiş ve alan yazından Kinney-Sedgwick ve Yochum (1996), Ulusoy ve Dedeoğlu (2011) tarafından geliştirilen görüşme formlarından yararlanılarak yeni bir görüşme formu elde edilmiştir. Geliştirilen görüşme formunun kapsam geçerliğini sağlamak için form bir öğretim üyesine, iki sınıf öğretmenine ve iki Türkçe öğretmenine inceletilmiştir. Yapılan incelemeler sonucunda formda bazı düzeltmeler yapılmıştır. Hazırlanan görüşme formu uygulanırken Kinney-Sedgwick ve Yochum'ın (1996) yaptığı uygulamaya benzer bir uygulama yapılmıştır. Uygulamada öncelikle öğretmenlerin içerik alanı okuma öğretimini kullanabilecekleri bir ders belirlenmiştir. İçerik alanları incelendiğinde sosyal bilgiler dersinde metinlerin daha fazla yer aldığı görülmüştür. Bunun sonucunda öğretmenlerin kullandıkları sosyal bilgiler kitabı incelenmiştir. Metinlerin uzunlukları ve içerikleri incelenerek kitaptan bir metin seçilmiştir. Seçilen metin Kurtuluş Savaşı'nı konu almaktadır. Metin belirlendikten sonra iki sınıf öğretmeni ile pilot görüşme yapılmış, bu görüşme sonucunda formda görülen eksiklikler giderilmiştir. Ayrıca görüşmenin tahmini süresi belirlenmiştir.

\section{Verilerin Toplanması}

Araştırmacılar, öğretmenler ile görüşme yapma konusunda gönüllü olup olmadıkları konusunda görüşmüştür. Gönüllü öğretmenlerle uygun zamanlar belirlenmiş ve bu zamanlarda görüşmeler gerçekleştirilmiştir. Görüşme öncesinde öğretmenlerden belirlenen metni okumaları istenmiştir. Sonrasında bu metin üzerinden görüşme sorularına geçilmiştir. Görüşmede öğretmenlerden ses kaydı yapmak için izin istenmiş, izin veren öğretmenlerle yapılan görüşmeler kaydedilmiştir. Görüşme sonrasında öğretmenlerden alınan cevaplar soru başlıkları altında yazılı hale getirilmiştir. Betimsel analizin yapıldığı araştırmalarda bireylerin görüşlerine doğrudan yer verilmesi ve bunlardan yola çıkarak sonuçların açıklanması araştırmanın geçerliği için oldukça önemlidir (Yıldırım ve Şimşek, 2013). Bu nedenle araştırmanın geçerliğini sağlamak için araştırmada doğrudan alıntılara yer verilmiştir. Araştırmanın iç geçerliğini sağlamak için çalışmanın yapıldığı ortam ile uzun süreli etkileşim içinde olmak ve katılımcı teyidi sağlamak gibi uygulamalar yapılmıştır (Başkale, 2016). Görüşmeci - çalışmanın birinci yazarı - sınıf öğretmeni olarak görev yapmakta ve sürekli olarak sınıf öğretmenleri ile etkileşim halinde bulunmaktadır. Araştırma boyunca araştırmacı hem veri toplama sürecinde hem de verilerin yorumlanmasında araştırma grubu ile etkileşim halinde olmuştur. 
Araştırmanın sonuçları araştırma grubu ile paylaşılmış katıımcıların araştırma sonuçlarına katıldığı görülmüştür.

Dış geçerlik araştırmanın sonuçlarının genellenebilirliği ile ilgilidir. Eğer bir araştırmanın sonucu benzer ortamlara ve durumlara genellenebiliyorsa araştırmanın dış geçerliğinin olduğu söylenebilmektedir (Yıldırım ve Şimşek, 2013). Araştırmanın benzer ortamlara ve durumlara genellenebilmesi araştırma grubu ile yakından ilgilidir. Bu nedenle araştırma grubunun detaylı olarak tanımlanması gerekmektedir (Başkale, 2016). Araştırma grubuna bakıldığında cinsiyet, kıdem, mezun olunan okul ve çalışılan kurum bakımından farklı özellikteki öğretmenlerden oluştuğu görülmektedir. Özellikle araştırma grubundaki öğretmenlerin kıdemlerinin ve çalıştıkları kurumların farklılık göstermesi elde edilen sonuçların genellenebilirliği için oldukça önemlidir.

Araştırmanın dış güvenirliğinin sağlanması araştırma aşamalarının detaylı olarak aktarılmasına bağlıdır. Çünkü tekrarlanacak başka bir çalışmanın aynı sonuçlara ulaşılabilmesi çalışma grubunun, çalışma ortamının veya araştırmacıların özelliklerinin benzerlik göstermesine bağlıdır (Yıldırım ve Şimşek, 2013). Bu nedenle araştırmanın nasıl bir ortamda gerçekleştirildiğinin detaylı olarak ortaya konması gerekmektedir. Araştırmacı çalışılan konu ile ilgili hem gözlemci hem de uygulayıcı olarak farklı zamanlarda görev almıştır. Bu nedenle konu ile ilgili belli bir deneyim sahibidir. Araştırmacı okul ortamında öğretmenlerin boş saatlerinde ya da okul bitiminde görüşmelerini gerçekleştirmiş̧ir. Görüşme esnasında öğretmenlerin kendilerini rahat hissedecekleri bir ortam oluşturulmuştur. Özellikle öğretmenlerin araştırmacıyı tanıyor olmaları onlara görüşlerini açıklayabilecekleri rahat bir ortam hazırlamada etkili olmuştur. Öğretmenlerle yapılan görüşmelerin bir kısmında ses kaydı alınırken bir kısmında araştırmacı tarafından notlar tutulmuştur. Görüşmeler bir sohbet havasında gerçekleştirilmiş, görüşme formundaki sorular belli bir sıra ile öğretmenlere sorulmuş, soruların sırasına özen gösterilmeye çalışılmıştır. Görüşme sonunda görüşmenin kısa bir özeti alınan notlar üzerinden yapılmıştır.

\section{Verilerin Analizi}

Araştırmadan elde edilen veriler betimsel analiz tekniği kullanılarak analiz edilmiştir. Betimsel analiz tekniği araştırmanın kavramsal yapısının önceden açık olarak belirlendiği araştırmalarda kullanılmaktadır. Bu teknikte görüşülen kişilerin görüşlerini çarpıcı bir şekilde yansıtmak için doğrudan alıntılara çokça yer verilir. Bu analiz türündeki amaç elde edilen bulguları düzenlenmiş ve yorumlanmış bir şekilde okuyucuya sunmaktır (Yıldırım ve Şimşek, 2013). Araştırmada öncelikle elde edilen veriler araştırma problemleri çerçevesinde düzenlenmiştir. Öğretmenlerin sorulara verdikleri cevaplar teker teker yazılı hale getirilmiştir. Öğretmenlerin cevapları arasında bağlantılar kurularak cevapların benzer ve farklı yönlerinden hareketle ortaya bir çerçeve çıkarılmıştır. Bu çerçeve 


\section{Sınıf Öğretmenlerinin İçerik Okuma ile ilgili Görüşleri}

içerisinde elde edilen bulgular doğrudan alıntılar ve diğer araştırma sonuçları ile yorumlanarak sunulmuştur.

\section{Bulgular}

\section{Sınıf öğretmenlerinin içerik okuma ile ilgili aldıkları eğitim nedir?}

Öğretmenlerle yapılan görüşmeler sonucunda Ö15 hızlı okuma kursu aldığını belirtmiştir. Bunun yanında Ö9, okuma - yazma öğretimi ile ilgili ses temelli cümle yöntemine geçişte bir eğitimin verildiğini belirtmiştir. Bu eğitimlerin dışında öğretmenlerin okuma ya da içerik okuma ile herhangi bir eğitim almadıkları görülmüştür.

2- Sınıf öğretmenleri alan derslerinde ders kitabındaki metinleri hangi sıklıkta ve nasıl kullanmaktadır?

Öğretmenlerle yapılan görüşsmeler sonucunda öğretmenlerin ders kitaplarındaki metinleri hangi sıkıkta kullandıkları Tablo 2'de frekansları ile sunulmuştur.

Tablo 2.Sınıf öğretmenlerinin derslerinde ders kitaplarındaki metinleri kullanma durumları

Ders kitaplarındaki metinleri kullanma durumu

Her zaman

Bazen

Hiçbir zaman
Öğretmen sayısı (f)

17

2

1

Tablo 2'den anlaşıldığı üzere sınıf öğretmenlerinin büyük bir bölümünün ders kitaplarındaki metinleri kullandığı görülmektedir. Öğretmenler metinleri farklı amaçlarla kullanmaktadırlar. Öğretmenler, önceki konularla bağlantı kurmak, ön bilgileri harekete geçirmek ya da sadece okuma becerisinin gelişmesi için metni okuttuklarını belirtmişlerdir. Ö15 kitaptaki metinleri kullanma sıklı̆ı ve nedeni ile ilgili "Her ders okuma mecburen yaptırıyorum. Derse giriş yapmadan önce bir önceki konuyla bağlantısını yapıp, konuya o şekilde girerim."demiştir. Ö14 ise yaptığı uygulamayı "Her ders mutlaka okuturum. Okuttuktan sonra kendim anlatırım." şeklinde ifade etmiştir. Bu öğretmenlerin yaptıkları okutma eyleminde ön bilgileri harekete geçirme amacı güttükleri söylenebilir.Ö9 ise "Her ders okuma yaptırıım. Bu metin bağlayıcı olmuyor ama genelde okutuyorum. Okumaları gelişmesi için." diyerek metne bağlı kalmamasına rağmen öğrencilerin okuma becerilerinin gelişmesi için metni okuttuğunu belirtmiştir.

Kitaplardaki metinlerin kullanılmadığı ya da az kullanıldığı durumlarla da karşılaşılmıştır. Ö1 bu durumu "Ders kitabını ara sıra kullanırım. Genelde konuyu hikâyeleştirerek anlatırım. Okumayı genelde Türkçe dersinde kullanırım." şeklinde ifade etmiştir. Ö7 ise "Çoğunlukla kullanmam. Metne bağlı kalmam, konuyu kendim anlatırım."diyerek derste okuma etkinliğini kullanmadığını ortaya koymuştur. Bunun dışında Ö18 "Ders kitabı içeriğini yeterli bulmadığım için Türkçe haricindeki 
derslerde uygulama harici kullanmıyorum." diyerek ders kitaplarının içeriğini uygun bulmadığını belirtmiştir.

Öğretmenlerin metni nasıl kullandıklarına bakıldığında bazı öğretmenlerin derse hazırlanmaları için öğrencilerden dersten önce metni okumalarını istedikleri görülmüştür. Ö15 bu durumu “Bloom'un tam öğrenme modelinde ön bilgilerin önemli olduğu belirtiliyor. Bu nedenle öğrencilerin evde metni okumalarını isterim. Hem metni okuyacak, hem araştırma yapacak hem de aklına takılan soruları hazırlayacak." şeklinde belirtmiştir. Burada öğretmenin üzerinde durduğu konunun öğrencilerin o günkü konu ile ilgili ön bilgilerini harekete geçirmek olduğu görülmektedir. Ö13 ise öğrencilere metni ödev olarak verdiğini belirtmiştir.

Bazı öğretmenler ise metinleri evde okutmadığını belirtmiştir. Ö4 bu durumu "Öğrencilere eve ders kitaplarını okuma vermiyorum. Evde okuyup okumayacağını bilemeyiz. Anlayıp anlamadığını belirleyemeyiz. Okuma sırasında zorluk çekebilirler. Bu durumda onlara yardımcı olacak kimse olmayabilir. Fakat benim yanımda okuduklarında ben onlara yardımcı olabilirim." şeklinde ifade etmiştir. Burada öğrencilerin bu metinleri anlamada zorluk çektiklerine dair bir vurgu yapılmaktadır. Yine benzer şekilde Ö8 "Metin ağır değilse evde okuyup gelirler. Bu metinleri sınıfta okutmam. Fakat metin zorsa sınıfta metni okuruz." diyerek öğrencilerin zorlanacağı metinlerin sınıfta ele alındığını belirtmiştir.

Öğrencilerin ön bilgilerine yönelik yapılan yukarıdaki uygulamaların yanı sıra öğretmenlerin ön bilgilerine yönelik olarak da metnin sınıfta okunabildiği görülmüştür. Ö2 bu durumu “Eğer konuya hazırsam metni okutmam. Genelde konuyu kendim anlatırım ya da materyallerden yararlanırım. Ancak hazır değilsem bir öğrenciye metni sesli olarak okuturum." şeklinde ifade etmiştir.

3-Sınıf öğretmenleri metni okutmadan önce ne yapmaktadırlar? Metinde anlamı bilinmeyen kelimeler ile ilgili çalışmalar nasıl yapılmaktadır?

Bir metni okumadan önce o metni anlamak için yapılabilecek bazı uygulamalar bulunmaktadır. Sınıf öğretmenlerinin bu uygulamalardan bazılarını yaptıkları görülmüştür. Sınıf öğretmenlerinin metni okumadan önce yaptıkları uygulamaların neler olduğu Tablo 3'te sunulmuştur.

Tablo 3. Sınıf öğretmenlerinin metin okunmadan önce yaptıkları uygulamalar

\begin{tabular}{lc}
\hline Yapılan Uygulamalar & Uygulayan Toplam Öğretmen Sayısı (f) \\
Soru - cevap & 7 \\
Anlatım & 6 \\
Görselleri incelemek & 2 \\
Tahmin yapma & 2 \\
Kelime çalışması & 1 \\
\hline
\end{tabular}




\begin{tabular}{ll}
\hline Araştırma ödevi & 1 \\
Beyin fırtınası & 1 \\
Zihin haritası & 1 \\
Soru oluşturma & 1 \\
Özet yapma & 1 \\
\hline
\end{tabular}

Tablo 3'te görüldüğü gibi bir metin okunmadan önce sınıf öğretmenlerinin soru sorma ve anlatım tekniklerini çoğunlukla kullandıkları görülmektedir. Ö8 "Öğrencilere ön bilgilerini yoklayıcı sorular sorarım. Metni anlamaları için güdülerim.", Ö12 "Önce eski derslerle bağlantısını kurarım. Soru cevap ile öğrencileri işin içine katarım.", Ö4 "Konu ile ilgili genel bir hatırlatma yapılır. Önceki konu ile bağlantılar sağlanır. Öğrencilere sorular sorulur." diyerek okuma öncesinde öğrencilerin ön bilgilerini açığa çıkarmak için soru-cevap ve anlatım tekniklerini kullandıklarını belirtmişlerdir. Soru cevap ve anlatım tekniğinin dışında tahmin etme, görselleri inceleme, kelime çalışması, araştırma ödevi, beyin fırtınası, zihin haritası, soru oluşturma, özet yapma gibi uygulamaların nadiren yapıldığı anlaşıımıştır. Bu durum anlamı yapılandırma sürecinde öğrencinin aktif olmasını sağlayan ve anlama sürecini kontrol etmesini sağlayacak etkinliklerin okuma öncesinde fazla yapılmadığını ortaya koymaktadır.

Bazı öğretmenlerin öğrencilerden derse gelmeden önce metni evde okumalarını istedikleri görülmüştür. Ö2 "Öğrencilerden metni evde okumalarını isterim. Okuyup gelen öğrencilerle hazırlı soruları cevaplanır. Varsa görseller yorumlanır. Görsellerle ilgili sorular sorulur.", Ö3 "Öğrencilerden evde konuyu okumalarını isterim. Resimlerini incelemelerini isterim. Soru cevap şekilde konuyu anlatırım.", Ö11 "Metni sınıfa çalışıp gelirler, araştırıp gelirler. Bilgilerini bizimle paylaşacak olup olmadığını sorarım." diyerek öğrencilerin evde yaptıkları okumanın üzerine sınıfta farklı yöntemlerle konunun işlendiğini belirtmişlerdir.

Öğrencilerin bir metni anlaması, o metindeki kelimelerin anlamını bilip bilmemesi ile yakından ilgilidir. Bu nedenle herhangi bir metni anlamak için o metne ilişkin kelimelerin anlamlarının öğrenilmesi gerekir. Sınıf öğretmenlerinin bilinmeyen kelimeler ile ilgili yaptıkları çalışmalara baktığımızda bazı öğretmenlerin bu kelimelerin üzerine eğildiği görülmüştür. Ö1 "Öğrenciler metinde bilmedikleri kelimelerin altını çizer. Bu kelimeler birer cümlede kullanılır. Bu cümleler tekrar okutulur.", Ö11 “Öğrenciler kelimeleri genelde cümlenin gelişinden tahmin ediyorlar. Sınıfta beyin fırtınası yapılıyor. Tahmin yanlışsa sözlüğe bakılıyor.", Ö12 "Anlamı bilinmeyen kelimeler önce öğrencilere sorulur. Anlamı bilen öğrencilerden dinlenir. Sözlüklerden bakılır. Gündelik hayat ile bağlantıları kurulur. Sosyal bilgiler dersinde bu sıkıntı oldukça fazladır.", Ö15 "Genelde sözlüğe baktırmadan önce cümleyi okuturum. Cümleden bu kelimenin ne dediğini anlayabiliyor mu, onu sezdirmeye çalışıyorum. Daha sonra sözlükten anlamı bulmasını istiyorum." diyerek yaptıkları uygulamaları belirtmişlerdir. 
Burada anlamı tahmin etme, gündelik hayatla ilişki kurma, bağlamdan anlamı çıkarma gibi uygulamalar yapıldığı görülmektedir. Bu görüşlerin yanında bilinmeyen kelimeler ile ilgili öğrencilerin pasif kaldıkları uygulamaların da yapıldığı ifade edilmiştir. Ö5 "Sözcük çalışması yapmam. Bilinmeyen kelimelerle ilgili genelde ben açıklama yaparım." derken Ö14 "Bilinmeyen kelimeleri ben kendim açıklarım, örneklerle birlikte." diyerek bu durumu ortaya koymuşlardır. Ayrıca Ö8, "Zaman çok yeterli değil. Daha çok öğrenciler sorduğunda cevaplarım." diyerek zamanın azlığından şikâyet etmektedir.

\section{4- Sınıf öğretmenleri metindeki önemli fikirleri nasıl ortaya çıkarmaktadır?}

Bilgilendirici metinlerde ana fikir, yardımcı fikirler ve detaylar birbirine bağlı bir yapı içerisinde yer alırlar. Bu metinlerden çıkarımda bulunmak bu fikirleri ve aralarındaki ilişkileri belirlemeye bağlıdır. Sınıf öğretmenlerine metinlerdeki önemli fikirlerin nasıl belirlendiğini sorduğumuzda öğrencilerin önemli fikirleri belirlemede yetersiz kaldıklarını belirtmişlerdir. Ö14, "Önemli bilgileri ben belirlerim. Öğrencilerin belirlemeleri çok zor." diyerek bu durumun öğrenciler için zor olduğunu belirtmiştir. Ö7 bu konuda, "Öğrenciler bağımsız olarak metindeki önemli detayları belirleyemezler. Mutlaka öğretmen tarafından görsellerle desteklenmelidir. Hazırladığım sorular etrafında önemli detayları ögrencilerle belirlerim. Tahtaya yazıp defterlerine geçmelerini isterim." diyerek sınıfta yaptığı uygulamayı aktarmıştır. Bir diğer öğretmen "Her öğrenci okuduğundaki önemli fikirleri organize edemez. Sorular sorarak öğrencilerin ana fikri belirlemesini isterim. (Ö8)" derken başka bir öğretmen "Önemli yerlerin altını çizdiririm. Bu metinde mesela tarihleri, savaşları ve kimler arasında yapıldığının önce altları çizilir sonra deftere not aldırılır." diyerek önemli fikirlerin genellikle öğretmenler tarafından belirlendiğini belirtmişlerdir.

Bazı sınıf öğretmenlerinin soru cevap yöntemi ile önemli fikirleri belirledikleri görülmüştür. Ö13 "Öğrencilerin soru cevap ile ana fikri belirlemeleri isteniyor. Yönlendirici ben oluyorum. Çocuklarda farklı yorumlar çıkarma yeteneği çok az. Çocukların gitgide daha çok beyinleri uyuşuyor." diyerek derste kullandığı yöntemden bahsetmiştir. Ö3 ise "Soru sorarak onların bulup altlarını çizmesini isterim. Çocuklardan sorular oluşturmalarını isterim. Onların soruları sonucunda önemli fikirlere ulaşılabilir." diyerek soru sormanın yanı sıra öğrencilerin de soru sorduklarını belirtmiştir.

Sınıf öğretmenlerinin derslerinde içerik alanı okuma öğretiminde kullanılan stratejileri kullandıkları da görülmüştür. Ö16 "Öğrencilerle kavram haritaları oluştururuz. Maddelendiririz, çizeriz, renkli çizimler oluştururuz." diyerek dersinde kavram haritalarını kullandığını belirtmiştir. Bir diğer öğretmen Ö10 “Önemli detaylardan kronolojik bir sıralama yaparım. Öğrencilerin zihinsel bir harita oluşturmalarını sağlamaya çalışırım. Öğrencilerle metni okumaya başlamadan önce konuya vakıf olması için bu çalışmaları yaparım. Böylece önemli detayların daha iyi farkına varabileceklerdir." diyerek dersinde açık olarak belirtmese de metin yapılarına vurgu yaptığı görülmektedir. Ancak yine 
Sınıf Öğretmenlerinin İçerik Okuma ile ilgili Görüşleri

de öğretmenler stratejileri kullansalar da öğrencilere bu stratejileri nasıl ve ne zaman kullanacaklarına ilişkin bir öğretim gerçekleştirmemektedirler.

5- Sınıf öğretmenleri metni öğrencilere nasıl okutmaktadır ve metin okunurken öğretmenin rolü nedir?

İçerik alanlarında okuma özellikle sosyal bilgiler dersinde sıklıkla kullanılmaktadır. Öğretmenlerin sınıflarında yaptırdıkları okuma uygulamalarına baktığımızda öğretmenlerin farklı şekillerde okuma yaptırdıkları görülmektedir. Bazı öğretmenler metinleri sınıfta dönüşümlü okuttuklarını belirtmişlerdir. Bu öğretmenler her öğrenciye okuma yaptırmaktadırlar. Bu konuda Ö9 "Öğrencilere sırayla metni okuturum. Bütün öğrencilerin eşit olarak metni okumasını sağlarım." diyerek her öğrencinin metni okumasını sağladığını belirtmiştir. Bunun dışında bazı öğretmenler öğrencilerin dikkatini metne odaklamak için metni karışık bir şekilde okuttuklarını vurgulamışlardır. Ö1 bu konuda "Öğrencilere bölüm bölüm karışık olarak okuturum. Karışık okutmamdaki amaç dikkati dağılmasın ve dersten kopmasın." derken Ö14 "...sonra paragraf paragraf rastgele okuturum. Rastgele okutunca öğrenciler takip etmektedirler." demektedir. Ö4 ise bölüm bölüm yerine rastgele bir öğrenciye okuttuğunu belirtmiştir.

Öğretmenlerin yaptıkları bu uygulamadan farkı olarak bazı öğretmenler derslerinde iyi okuyan öğrencilere öncelik verdiklerini ifade etmektedirler. Ö5 metni sadece anlamlı okuyan öğrencilere okuttuğunu belirtmiştir. Ö15 okuma sorunu olan öğrencilerin derste okurken karşılaştıkları sorunları şu şekilde söylemiştir: “Okuması kötü olan öğrencileri dinlemiyorlar. Diğer öğrenciler yanlışı düzeltmeye çalışıyor. Diğer öğrenci de okumak istemiyor. Öğrencilere yönlendirme yapıyorum. Arkadaşlarına alınmaması gerektiğini söylüyorum." Ö15 okuma becerisi gelişmemiş olan öğrencilerin karşılaştıkları sorunlara vurgu yaparak bu durumun sınıfta oluşturduğu sorunları ortaya koymaktadır. Ö16 ise genelde iyi okuyuculara okutmasına rağmen zayıf okuyuculara da zaman zaman okuma yaptırdığını "Anlaşııır okuyanlara daha çok öncelik veririm. Kötü okuyana da okuturum en azından okurken öğrensin." diyerek belirtmiştir.

Öğrenciler okurken öğretmenlerin yaptıkları uygulamaların iki başlık altında gruplandığı görülmektedir. Bunlardan birincisi metinde yer alan önemli fikirlerin belirlenmesi ile ilgili öğretmenlerin yaptıkları davranışlar, ikincisi ise öğrencilerin okuduğunu anlama becerisini geliştirmeye yönelik davranışlar olarak görülmüştür. Öğretmenlerin metindeki önemli fikirleri belirlerken izledikleri yöntem öğrencilerin okurken önemli yerde durmaları ve bunun üzerinden soru cevap veya öğretmenin açıklamaları ile önemli fikirlerin belirlenmesidir. Bu durumu Ö3 "Belli bir yerde durdurup o bölümün üstünden soru cevap ile geçerim.", Ö4 "Önemli yerlerde öğrenciyi durdururum. Gerekli açıklamaları yaparım.", Ö5 “Öğrenciler okurken cümle cümle, paragraf paragraf okutup ne anladıklarını sorarım.", Ö10 "Zaman zaman okumaları keserim. Öğrencilerin başta 
anlattıklarımız üzerine yerleştirmeye çalışıız.", Ö12 "Öğrenciyi önemli yerlerde durdurur, o yerin altını çizmelerini isterim.", Ö16 "Öğrenciyi takip ederim, irdelerim, okumayı cümle bazında kesip açıklama yaparım." diyerek belirtmişlerdir.

Sınıfta okuma yapılırken öğretmenlerin öğrencilerin okuma becerisini geliştirmeye yönelik uygulamalarda da bulunduğu görülmektedir. Öğretmenlerin öğrenciler okurken genelde benzer uygulamalar yaptıkları görülmüştür. Bu konuda Ö3, "Telaffuz hatalarını anında düzeltirim. Noktalama işaretlerine vurgu ve tonlamaya dikkat ederim." derken Ö14 "Öğrenciyi gözlemlerim. Öğrencilerin noktalama işaretine dikkat ederek okumalarını isterim. Öğrencilerin soru cümlesi geldiğinde soru anlamı katmasını, insan konuştuğunda konuşuyormuş gibi okumasını isterim. Buna her derste dikkat ederim." demiştir. Ö15 ise "Tonlamaya hangi ders olursa olsun, soru tonlaması, konuşma tonlaması, dikkat etmelerini isterim. Sadece hızı düşünmemeleri gerekmektedir. Öğrenci hızlı hızlı okuyup geçmek istiyor. Okurken noktalamalara mutlaka dikkat ediyoruz." diyerek yaptığı uygulamayı belirtmiştir. Öğretmenlerin yaptıkları bu uygulamalarlaöğrencilere anlamayı sağlayacak noktalardayardımettikleri görülmektedir.

\section{6- Sınıf öğretmeni okumayı bitirdikten sonra neler yapmaktadır?}

Okuma sonrasında okunulanın anlaşııması, kalıcı olması ya da başka konularla ilişkilendirilmesi için bazı uygulamalar yapılmaktadır. Yapılan araştırmada okuma sonrasında öğretmenlerin farklı uygulamalarda bulundukları anlaşılmıştır. Sınıf öğretmenlerinin okuma sonrasında yaptıkları uygulamalar Tablo 4'te sunulmuştur.

Tablo 4.Sını öğretmenlerinin metin okunduktan sonra yaptıkları uygulamalar

\begin{tabular}{lc}
\hline Yapılan Uygulamalar & Uygulayan Toplam Öğretmen Sayısı (f) \\
Soru sorma & 11 \\
Önemli yerlerin altını çizdirme/yazdırma & 7 \\
Özetleme & 4 \\
Test çözme & 3 \\
Kitaptaki etkinlikler & 2 \\
Bulmaca & 1 \\
Soru oluşturma & 1 \\
Zihin haritası & 1 \\
Soru oluşturma & 1 \\
\hline \multicolumn{1}{|l}{ Tablo 4'te görüldüğü üzere sınıf öğretmenleri okuma sonrasında çoğunlukla soru sorarak } \\
okunulan metnin anlaşılmasına yönelik uygulamalar yapmaktadırlar. Ö16 “Öğrencilere sorular \\
sorarak öğrencilerin önemli noktaları görmesini sağlarım.” diyerek ders sonrası soru sorma \\
etkinliğinde bulunduğunu belirtmiştir. Yine Ö9 “Ders bitiminde onunla ilgili bir iki soru sorarım
\end{tabular}


Sınıf Öğretmenlerinin İçerik Okuma ile İlgili Görüşleri

anlamışlar mı diye. Öğrenci tekrar etmiş oluyor. Zaman sıkıntısından dolayı daha çok soru sorulmuyor. Zaman olsa daha çok soru sorulabilir." diyerek soru sorma etkinliğini kullandığını ifade etmiştir. Ö9’a benzer şekilde Ö12 de "Okuma bittikten sonra soru cevap kullanırım. Onların kavrayıp kavramadıklarına bakarım. Çoğunlukla okuma bittikten sonra vakit kalmıyor. Onun için bir şey yapmıyorum. Eğer yapılacak etkinlik kalırsa eve ödev veririm." diyerek soru etkinliğini kullandığını ancak zaman sıkıntısı yaşadığını belirtmiştir.

Soru sorma ile beraber yapılan etkinliklerden biri de metnin özetlenmesidir. Ö8 "Anlamaya yönelik sorular sorarım. Konuyu özetlemeye çalısıırım. Özetlemeyi öğrenciler zor yapmakta. Onların yerine beraberce özet çıkarıız." diyerek sorular yardımıyla metnin bir özetini yaptığını belirtmiştir.Ö10 "Öğrencilerden daha önce oluşturduğumuz zihin haritasını kullanarak özet yapmalarını isterim. Çocuğun birebir anlatmasından ziyade genel olarak anlatmasını isterim. Fakat öğrenciler birebir özetlemeyi istiyorlar. Cümle cümle bunu özetlemek istiyor. Özet yaparken oradaki herhangi bir şeyi anlatamadığında öğrenci orda kalıyor ve anlatamıyor. O küçük detayı genelleyip özete devam edemiyor." diyerek öğrencilerin özet yaparken yaşadıkları zorluklara değinmiştir. Yine benzer şekilde Ö2 "Öğrenciler özet yapamıyorlar. Önemli yerleri ben söylerim onlar altlarını çizerler. Metin sonunda sorular sorulur. En son deftere önemli yerleri yazarız. Ben söylerim onlar yazar." şeklinde sorulardan yararlanarak önemli yerlere vurgu yaptığını ve daha sonra bunların deftere yazıldığını belirtmiştir. Öğretmen görüşlerinden öğrencilerin metni özetlerken zorlandıkları anlaşılmaktadır. Bu zorluğu aşmak için genelde öğretmenler önemli yerleri tahtaya yazarak ya da altını çizdirerek öğrencilerin defterine not etmelerini sağlamaktadırlar.

Öğretmenlerin okuma sonrasında yaptıkları diğer bir uygulama ise o konuyla ilgili testlerin okuma sonrasında çözülmesidir. Ö1 “Özetleme olarak önemli yerlerin altını çizdiririm. Konu bittikten sonra hem test kâğıdı veririm hem de sorular sorarım.", Ö4 ise "Konuyla ilgili testler çözeriz. Öğrencilerle beraber sorular hazırlanır. Sorular çözülür. Özetleme yaptırılmaz." diyerek okuma sonrasında konunun pekiştirilmesi için testlerden yararlanıldığını belirtmişlerdir. Ayrıca bir öğretmen "Bu konu ile ilgili bulmaca bulurum. Anahtar kelimeler ile ilgili bulmaca. Önemli detayları not tuttururum. (Ö11)" diyerek konu sonrasında farklı ölçme yöntemlerini kullandığını belirtmiştir.

7- Öğrencilerin içerik okuma sırasında karşılaştıkları sorunlar nelerdir? Sınıf öğretmenlerin karşılaşılan bu sorunlara yönelik çözümleri nelerdir?

Öğretmenler öğrencilerin içerik alanında okurken fikirler arasında bağlantı kurmada, farklı kavramları tanımada ve akılda tutmada, tarih ve şehir isimlerini akılda tutmakta zorlandıklarını ifade etmişlerdir. Ö2 "Öğrenciler metindeki fikirler arasında bağlantı kuramıyor. Metne dikkatini veremiyorlar. Dikkatini toplayamıyor." diyerek öğrencilerin fikirler arasında bağ kurmada zorlandığını 
ifade etmektedir. Bu soruna ise öğrencinin okuma hızının yavaş olmasının neden olduğunu belirtmiştir. Bu sorunu çözmek için Türkçe dersinde okuma yarışı yaptırdığını ayrıca anlama becerilerinin gelişmesi için 5N1K çalışmalarına yer verdiğini belirtmiştir.

Önemli fikirlerin yanı sıra öğrencilerin metindeki farklı kavramları, isimleri, kısaltmaları, tarihleri, yer adlarını anlamada ve akılda tutmakta zorlandıkları ifade edilmiştir. "Öğrenciler genelde değişik kavram ve kelimelerle ilgili zorluklarla karşılaşırlar. Mondros Ateşkes Antlaşması'nı bilmeyebilirler (Ö4).", "Metnin içinde bazı anlamadığı noktalar olabilir. Bazı başarılı öğrenciler anlamadığı noktayı anında öğretmene sorar. 'Öğretmenim MS yazıyor, bu ne demek?' diyor. Bazı öğrenciler bir an önce geçiştirmek istiyor. Bilmediği kelimeler, simgeler, işaretlerle karşılaşır. Anlamadığı, deyimler, atasözleri olur.(Öو)" gibi öğretmen ifadeleri bu durumu ortaya koymaktadır. Burada ifade edilen öğrencilerin anlamadığı yerleri geçiştirmesi anlamanın önündeki önemli bir engel olarak görülmektedir. Oysa anlamadığının farkında olan öğrenci anlamadığı yerle ilgili bilgileri farklı kaynaklardan öğrenebilir. Ö9 bu konuda "Bu sorunları azaltmak için imla kılavuzu, sözlük, atasözleri, deyimler sözlüğ̈̈ mutlaka öğrencilerin yanında olmalıdır. Bunların kullanışı mutlaka öğrencilere öğretilmelidir. Sosyal bilgiler dersinde sözlük sürekli öğrencilerin elindedir. Öğrencilere bu alışkanlığı vermek çok önemlidir. Bunu Türkçe'de bir derste gösterip geçersek bunu alışkanlık haline getiremez. Bu nedenle her ders uygulanması gerek." diyerek anlamayı geliştirecek çalışmaların her derste uygulanması gerektiğini belirtmiştir.

Öğretmenlerin ifadelerinden bazı metinlerin öğrencilerin düzeyine uygun olmadığı ve öğrencinin metni anlamasını zorlaştırdığı anlaşılmaktadır. Bu durumu Ö11 “Metinlerde yoğun bilgi olması öğrenciyi yoruyor. Çocuğa soyut geliyor." şeklinde aktarırken Ö13 "Metin çok uzunsa sıkılırlar, anlama oluşmuyor. Bundan dolayı metnin özünü vermeyi önemli buluyorum." diyerek aktarmıştır. Ö16 ise "Geçmişte yaşanan bu konular öğrenciler için soyut olabilir. Ayrıntılı bilgiler belki sıkıcı olabilir. Önemli noktalar vurgulanabilir. Konuları görsel materyallerle zenginleştirerek daha anlaşılır kılarım." diyerek soyut konularla ilgili metinlerde anlama sorunu oluştuğunu vurgulamıştır.

\section{Tartışma, Sonuç ve Öneriler}

Bilgi kaynaklarına ulaşmanın kolaylaşması bilgiye ulaşmamızı sağlayacak becerilerimizin gelişmesini zorunlu hale getirmektedir. Birey artık çevrenin pasif bir alıcısı konumundan becerileri yardımıyla gerekli bilgiyi bulan, bilgiyi gerektiğinde kullanan bir konuma geçmiştir. Bu durum öğrencilerin bilgiyi elde etmeleri için gerekli olan becerilerinin geliştirilmesini gerektirmektedir.

Okuma bireyin dış dünyadaki bilgiyi elde etmesi için gerekli olan önemli becerilerden biridir. Bu nedenle üzerinde önemle durulmaktadır. Okuma dendiğinde karşımıza çok genel bir kavram çıkmaktadır. Öyle ki okuma, bir şiir okumaktan bir fıkra okumaya kadar birbirinden çok farklı 


\section{Sınıf Öğretmenlerinin İçerik Okuma ile İlgili Görüşleri}

metinlerin okunmasına dayanır. Bu durum okuma öğretiminin farklı türlere özgü olarak da geliştirilmesini gerekli kılar. Ne kadar güzel okursak okuyalım şiir okumak farklı bir beceri gerektirir. Bu durum bir fıkra için de geçerlidir. Bir başka metin türü olan bilgilendirici metinleri okumak da okumanın ötesinde farklı uygulamaların yapılmasını gerektirmektedir. Bilgilendirici metinler her hangi bir konu hakkında bilgi vermeyi amaçlayan metinlerdir. Farklı disiplin alanları ile ilgili bilgi sunmak için bilgilendirici metinlerden yararlanılır. Her disiplin alanı kendine özgü kavramlara, sembollere, uygulamalara sahiptir. Farklı disiplin alanlarına ait bu özellikler okunulan metinleri anlamayı zorlaştırmaktadır. Bu anlama zorluğunu ortadan kaldırmak için içerik öğretimi ile okuma öğretiminin bütünleştirildiği içerik okuma kavramı ortaya çıkmıştır. Bu araştırmada sınıf öğretmenlerinin içerik okuma ile ilgili uygulamalara derslerinde nasıl yer verdiklerinin ortaya konması amaçlanmıştır.

Araştırmada sınıf öğretmenlerinin okuma ile ilgili aldıkları eğitimlerin ilkokuma yazma öğretimine yönelik olduğu görülmüştür. Öğretmenler genel olarak 2005 yılında ilkokuma yazma öğretiminde yapılan yöntem değişikliği ile ilgili verilen seminerleri aldıklarını belirtmişlerdir. Sınıf öğretmenlerinin hizmet içi ihtiyaçlarını belirlemeye yönelik yapılan çalışmalarda ilkokuma-yazma öğretimi üzerinde durulduğu görülmektedir (Kaçan, 2004; Ergin, Akseki ve Deniz, 2012). Bu durum okuma dendiğinde aklımıza ilkokuma-yazma öğretimi geldiğini göstermektedir. Oysa okuma, kod çözmeden başlayıp anlamanın gerçekleşmesine kadar geçen gelişimsel bir süreçtir. Harfleri seslendirip bir araya getirmek anlamanın bir gereği olsa da anlama için yeterli değildir. Bu nedenle sınıf öğretmenlerine okuma becerisinin geliştirilmesine ve kullanılmasına yönelik eğitimlerin verilmesi önemlidir.

Ders kitapları öğretmenlerin derslerde kullandıkları önemli kaynaklardır. Kitaplarda yer alan metinler aracılığı ile bilgiler öğrencilere sunulmaktadır. Bu çalışmada sınıf öğretmenlerinin büyük bir kısmının alan dersi kitaplarındaki metinleri kullandığı görülmüştür. Derslerde metin kullanılırken genelde öğretmenin metin üzerinden dersin öğretimini gerçekleştirdiği, bu süreçte öğrencilerin belli etkinlikleri yaptıkları anlaşımıştır. Okuma öncesinde öğretmen sorduğu sorularla öğrencilerin ön bilgilerini ortaya çıkarmaktadır. Okuma esnasında öğrencilere önemli yerlerin altını çizdirmekte ya da deftere not aldırmakta, önemli yerleri açıklamaktadır. Okuma sonrasında ise soru sorarak, özet yapılarak ya da test çözülerek konunun tekrarı sağlanmaktadır. Mraz, Rickelman ve Vacca, (2009) yapılan bu uygulamaları geleneksel sınıfların bir özelliği olarak belirtmektedir. Bu sınıflarda öğrenciler bir metni okumak üzere ödevlendirilir. Öğrenciler metni okuduktan sonra metin üzerinden sorulan sorularla konu anlatılır. Ulusoy ve Dedeoğlu'nun (2011) yaptığı çalışmada da benzer sonuçlara ulaşılmıştır. Ulusoy ve Dedeoğlu (2011) tarafından yapılan çalışmada sınıf öğretmenlerinin soru sorma, bilinmeyen kelimeleri açıklama gibi uygulamalar yaptıkları belirtilmiştir. Yapılan bu 
uygulamalar öğrencileri pasif durumda bırakmakta öğretmenin konu ile ilgili bilgileri dersteki önemli belirleyici olmaktadır (Mraz, Rickelman ve Vacca, 2009).

Sınıflarda yapılan soru sorma, önemli bilgileri söyleme ya da bilinmeyen kelimeleri açıklama gibi öğretmen merkezli uygulamalar öğrencilerin bağımsız birer okur olmalarının yolunu açamamaktadır. Yapılan araştırmada bu durumu destekleyici bazı bulgulara ulaşılmıştır. Araştırmada bazı öğretmenler öğrencilerin içerik alanlarındaki metinleri tek başına anlayamadıklarını ifade etmişlerdir. Bu nedenle, metinleri okuma görevi olarak vermediklerini bile belirtmişlerdir. Öğrenciler bir metni okumakta ancak metni anlamlandırmada zorluk çekmektedirler. Bu durum öğrencilere anlamlandırma konusunda yardım edilmesini gerekli kılar. Örneğin, anlam kurmada bireyin ön bilgilerini kullanması oldukça önemlidir. Öğrencilere KWL (Bildiklerim-Bilmek İstediklerimÖğrendiklerim) stratejisi öğretildiğinde öğrenci bir metni okumadan önce kendi kendine "Bu metinle ilgili ne biliyorum?" sorusunu sorabilecektir. Bu, bir nevi ön bilgilerin aktif hale gelmesi demektir. Bunun yanında ne öğrenmek istediğini ve neler öğrendiğini ortaya koyması da yine kendi başına okuduğundan anlam çıkarması için oldukça önemlidir. Öğretmen rehberliğinde yapılan bu uygulamalar stratejiler yardımıyla öğrenci tarafından kendi kendine de yürütülebilir. KWL gibi birçok anlama stratejisi içerik alanlarında kullanılabilmektedir. Örneğin karşılıklı öğretim, 3D stratejisi (TWA), ISOAT (SQ3R), metin yapısı öğretimi bu stratejilere örnek olarak verilebilir. Sınıf öğretmenleri ile yapılan görüşmelerde çok az sayıda anlama stratejisinin kullanımına rastlanmıştır. Bu stratejilerin kullanımında ise öğretmenin ön planda olduğu görülmüştür.

Araştırmada bazı öğretmenlerin alan derslerinde metni kullanmadıkları ya da az kullandıkları görülmüştür. Öğretmenlerin metni kullanmama nedenini Keskin ve Baştuğ (2010) öğrencilerin okuduklarını anlayamamaları olarak belirtmiştir. Bu araştırmada öğrencilerin bu metinleri anlamada zorluk yaşadıkları ifade edilmesine rağmen metnin kullanılıp kullanılmamasında öğretmenin ve öğrencinin metne ilişkin ön bilgilerinin önemli olduğu düşünülmektedir. Bazı öğretmenler öğrenci düzeyine uygun ve somutlaştırılabilir konularda metni kullanmadıklarını ifade etmişlerdir. Konu öğrencinin rahat anlayacağı bir konuysa metinler üzerinden ders anlatmak yerine öğretmenin ya da öğrencilerin anlatımları üzerinden ders yürütülmektedir. Eğer konu ile ilgili ön bilgiler az ise tam tersi bir durum olmakta ve metnin vereceği bilgilerin öneminden dolayı ders metin üzerinden işlenmektedir. Burada karşımıza alan bilgisi öğretimi ile okuma becerisinin geliştirilmesi arasındaki eşgüdüm sorunu çıkmaktadır; "bilgi öğretimi mi, okuma öğretimi mi?”. İçerik okuma bu eşgüdümü sağlamaya yönelik yapılan uygulamaları kapsayan bir kavramdır. Öğrencilerin herhangi bir alan ile ilgili bilgilere ulaşmasını sağlayan okuma becerilerini geliştirmek içerik okuma uygulamalarının temel hedeflerinden biridir (Ness, 2005). İçerik okuma, öğrencilerin okudukları bilgilendirici metinlerden kendi kendilerine bilgiye ulaşmalarını hedefler. Bu açıdan bakıldığında öğrencilerin ön bilgilerinin 


\section{Sınıf Öğretmenlerinin İçerik Okuma ile ilgili Görüşleri}

yeterli olduğu anlamlandırılması kolay metinlerle mümkün olduğu kadar baş başa bırakılması onların metindeki bilgiye bağımsız olarak ulaşabilmeleri için bir fırsat sağlayacaktır. Öğrencilerin bu basit metinler yardımıyla strateji kullanımından alana özgü kelimelerin öğrenimine kadar birçok alanda kendilerini geliştirmeleri onların daha zorlu metinleri anlamalarına yardımcı olabilecektir.

Sınıf öğretmenlerinin özellikle birinci sınıftan itibaren okuma öğretimi üzerinde durmaları onların anlama stratejilerini küçük yaştan itibaren öğrencilere öğretebilmeleri için fırsat niteliğindedir. Bu nedenle öğretmenler, okuma öğretimi ile içerik alanlarının bütünleştirildiği örnek uygulamalar hakkında verilecek kurslar, hizmet içi eğitimler, seminerler ile bilgilendirilebilirler. Formal eğitimin önemli belirleyicilerinden biri olan öğretim programlarında "Her öğretmen Türkçe öğretmenidir." anlayışından hareketle farklı alanlara özgü okuma kazanımlarına yer verilmesi içerik alanları ile okuma öğretiminin bütünleştirilmesinde kolaylık sağlayacaktır. Yine önemli bir ders araç gereci olan ders kitaplarında sadece bilgi vermekten ziyade öğrencilerin metinleri anlamaları için farklı anlama stratejilerinin uygulaması yer alabilir. Sonuç olarak, öğrencilere farklı stratejilerin öğretiminden öğrencilerin ders kitaplarının geliştirilmesine kadar okuma becerilerini geliştirecek uygulamaların her alan ile bütünleştirilmesi; öğrencilerin bu alanlardaki bilgilere daha kolay ulaşmalarını sağlayarak onların bilgi çağının aktif bireyleri olarak yetişmelerine katkıda bulunacaktır.

\section{Kaynaklar}

Armbruster, B. B., Anderson, T. H. \& Meyer, J. L. (1990). Improving content area reading using instructional graphics. Technical Report No. 508.

Başkale, H. (2016). Nitel araştırmalarda geçerlik, güvenirlik ve örneklem büyüklüğünün belirlenmesi. Dokuz Eylül Üniversitesi Hemşirelik Fakültesi Elektronik Dergisi, 9(1).

Büyüköztürk, S., Kılı̧̧ Çakmak, E., Akgün, O. E., Karadeniz, S. \& Demirel, F. (2010). Bilimsel araştırma yöntemleri (4. bas.). Ankara: Pegem A Yayıncilık.

Cervetti, G. N., Barber, J., Dorph, R., Pearson, P. D. \& Goldschmidt, P. G. (2012). The impact of an integrated approach to science and literacy in elementary school classrooms. Journal of research in science teaching, 49(5), 631-658.

Coşkun, E. (2002). Okumanın hayatımızdaki yeri ve okuma sürecinin oluşumu. Türklük Bilimi Araştırmaları, 11(11), 239.

Demirel, Ö. (2012). Eğitimde program geliştirme: Kuramdan uygulamaya. Ankara: Pegem A Yayıncılık.

Dymock, S. \& Nicholson, T. (2010). "High 5!" strategies to enhance comprehension of expository text. The Reading Teacher, 64(3), 166-178.

Ergin, i., Akseki, B. \& Deniz, E. (2012). İlköğretim okullarında görev yapan sınıf öğretmenlerinin hizmet içi eğitim intiyaçları. Elektronik Sosyal Bilimler Dergisi, 42(42).

Grierson, S. \& Daniel, L. (1995, November). Understanding Attitudes of Educators toward Content Area Reading in the Early Elementary Grades. Paper presented at the meeting of the Mid-South Educational Research Association, Biloxi, MS.

Güneş, F. (2012). Okuma ve Zihni Yönetme. Mustafa Kemal Üniversitesi Sosyal Bilimler Enstitüsü Dergisi, 9(18), 1-15. 
Hall, L. A. (2005). Teachers and content area reading: Attitudes, beliefs and change. Teaching and Teacher Education, 21(4), 403-414.

Heller, R. \& Greenleaf, C. L. (2007). Literacy instruction in the content areas: Getting to the core of middle and high school improvement. Alliance for Excellent Education.

Kaçan, G. (2004). Sınıf öğretmenlerinin mesleki gelişime ilişkin isteklilik düzeyleri. Eskişehir Osmangazi Üniversitesi Sosyal Bilimler Dergisi, 5(1).

Karadağ, R. \& Çengelci, T. (2011). Sosyal bilgiler dersinde dil becerilerinin geliştirilmesine ilişkin öğretmen görüşleri. International Journal of Eurasia Social Sciences, 2011(3).

Kinney-Sedgwick, M. \& Yochum, N. (1996). Content area literacy instruction: Viewpoints of elementary teachers and literacy professors. Literacy Research and Instruction, 35(4), 298-314.

Ozan Leylum, Ş., Odabaşı, H. F., \& Kabakçı Yurdakul, I. (2017). Eğitim ortamlarında durum çalışmasının önemi. Eğitimde Nitel Araştırmalar Dergisi - Journal of Qualitative Research in Education, 5(3), 369-385. www.enadonline.com DOI: 10.14689/issn.2148- 2624.1.5c3s16m

Manzo, A. V., Manzo, U. C. \& Estes, T. H. (2001). Content area literacy: Interactive teaching for active learning. John Wiley \& Sons Incorporated.

McKenna, M. C. \& Robinson, R. D. (1990). Content literacy: A definition and implications. Journal of reading, 34(3), 184-186.

Mraz, M., Rickelman, R.J. \& Vacca, R.T. (2009). Content-area reading: Past, present, and future. In K.D. Wood \& W.E. Blanton (Eds.), Literacy instruction for adolescents: Research-based practice (pp. 77-91). New York: Guilford.

National Reading Panel. (2000). Report of the National Reading Panel: Teaching to children to read. An evidence-based assessment of scientific research literature on reading and its implications for reading instruction: Reports of the subgroups. National Institute for Literacy. Jessup, MD

Ness, M. K. (2016). Reading comprehension strategies in secondary content area classrooms: Teacher use of and attitudes towards reading comprehension instruction. Reading Horizons (Online), 55(1), 58.

Park, T. D. \& Osborne, E. (2006). Content area reading strategies and textbook use in agricultural education. Journal of agricultural education, 47(4), 1.

Sidekli, S. (2005). ilköğretim beşinci sınıf öğrencilerinin öğretici ve öyküleyici metinlere göre okuduğunu anlama becerilerinin sınanması. Yayımlanmamış yüksek lisans tezi, Gazi Üniversitesi Eğitim Bilimleri Enstitüsü, Ankara.

Taş, H. \& Kıroğlu, K. (2018). Türkiye ve ABD Kaliforniya Eyaleti Anadili Öğretim Programlarında ilk okuma yazma öğretimi. Journal of International Social Research, 11(56).

Tayşi, E. K. (2007). Illköğretim 5. ve 8. sınıf öğrencilerinin hikaye ve deneme türü metinlerindeki okuduğunu anlama becerilerinin karşılaştırılması (Kütahya ili örneği). Yayımlanmamış yüksek lisans tezi, Gazi Üniversitesi Eğitim Bilimleri Enstitüsü, Ankara.

Türnüklü, A. (2000). Eğitimbilim araştırmalarında etkin olarak kullanılabilecek nitel bir araştırma tekniği: Görüşme. Kuram ve Uygulamada Eğitim Yönetimi Dergisi, 6(4), 543-559.

Ulusoy, M. \& Dedeoglu, H. (2011). Content area reading and writing: Practices and beliefs. Australian Journal of Teacher Education (Online), 36(4), 1.

Vacca, R. T. \& Vacca, J. A. L. (2005). Content area reading. Boston: Little, Brown.

Williams, J. P., Stafford, K. B., Lauer, K. D., Hall, K. M. \& Pollini, S. (2009). Embedding reading comprehension training in content-area instruction. Journal of Educational Psychology, 101(1), 1.

Yıldırım, A. \& Şimşek, H. (2013). Sosyal bilimlerde nitel araştırma yöntemleri. (9. Baskı). Ankara: SeçkinYayıncılık. 
Yıldırım, K., Yıldız, M., Ateş, S. \& Rasinski, T. (2010). Illköğretim beşinci sınıf Türk öğrencilerin metin türlerine göre okuduğunu ve dinlediğini anlama düzeyleri. Elementary Education Online, 9, 44-51.

\section{Extended Abstract Introduction}

Classroom teachers focus on basic reading skills such as sound recognition, fluency, and reading comprehension with literary texts, short rhyme and poetryin the first years of the primary school. In the following years, texts in the textbooks are used for comprehension studies. The forth grade primary school students will have a difficult year because studentswho use very little informative texts are required to read texts in different content areas. The content area reading includes activities in different disciplines such as social sciences, science, mathematics. Content area reading can be defined as having reading comprehension skills which are essential to understand new content included in those disciplines. With reference to a common saying which is "every teacher is a reading teacher", it can be said that each lesson is a reading lesson. For this reason, it is crucial to improve comprehension skills of each and every student. The fact that content area teachers mostly focus on students' knowledge of the area, do not perceive themselves as teachers of reading and do not receive education in this field makes the reading practices of primary school teachers more important. For this reason, in this research, it is aimed to reveal the practices that primary school teachers are carrying out to teach reading in their content area.

\section{Method}

The research was carried out with 20 teachers who worked in Alaçam province of Samsun and determined by purposive sampling in 2015-2016 academic year. Qualitative research method was used in the study. The data of the research was collected by the researchers through semi-structured interview form which was formed by reviewing the literature. By using interview forms developed by Kinney-Sedgwick and Yochum (1996) and Ulusoy and Dedeoğlu (2011), and a new interview form was prepared. An application similar to Kinney-Sedgwick and Yochum (1996) used was preferredduring the application period of the prepared interview form. During the application, a course in which teachers can use reading instruction in content areahas been identified. A text was selected from a textbook. Next, pilot interviews were held with two primary school teachers, and the shortcomings of the form were revisedby the help of of those interviews. The estimated duration of the interview was also determined. During the analysis of qualitative data, descriptive analysis method was used.

\section{Result and Discussion}

As a result of the research, it was determined that the class teachers did not take any courses related to reading apart from primary school reading-writing instruction.Textbooks are important sources which teachers use in their lessons. In this study, it was seen that some of the teachers did not use texts at all while some of themused. It was revealed that in this research students' and teachers' prior knowledgeabout the textwere important. Some teachers stated that texts weren'tsuitable to students' level and did not offer concrete contexts. If the subject was easy to understand by the student, the was taught by the teacher or the students' expressions instead of using texts. If the prior knowledge about the subject was insufficient, the subject was explainedby using the text considering the importance of the information that text was offering. While the texts were being used in the lessons, it was understood that the students performed certain activities when the classroom teacher taught through to the text.The questions that the teacher asked before reading activity revealed the students' prior knowledge. During the reading, the teacher underlined the important points, explained them and made students take notes. After reading, the subject wasreviewedby summary or test. Mraz, Rickelman and Vacca (2009) state that these practices are features of traditional classes. In these classes, students are given a chance to read a text. After students read the text, the topic is discussed with the questions asked about the text. Ulusoy and Dedeoğlu's (2011) work shows similar results. In the study conducted by Ulusoy and Dedeoğlu (2011), it was stated that class teachers are making applications such as asking questions, explaining unknown words. These practices leave the students in a passive state and the teacher is an important determinant in the subject (Mraz, Rickelman and Vacca, 2009). In the research, some recommendations were made to make students active while they are reading in the content areas. 